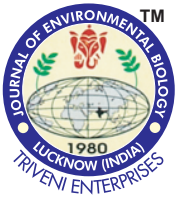

\title{
Assessment of hydrogeoecological features of the Yesil River Basin
}

\section{Authors Info}

\section{Z.A. Amirzhanovna',}

K.M. Zhanaleyeva',

B.Z. Galimzhanovich',

K.T. Saparov', E. H. Mendybayev ${ }^{2}$ and $\mathrm{E}$. Atasoy ${ }^{3 *}$

'Department of Geography,

Faculty of Natural Sciences,

L.N.Gumilyov Eurasian National

University, Astana, 010000 ,

Kazakhstan

${ }^{2}$ Department of Ecology, Faculty of Natural Science, K.Zhubanova Aktobe Regional State University, Aktobe, 120505Kazakhstan

${ }^{3}$ Department of Primary Education and Social Sciences, Faculty of

Education, Uludag University,

Bursa, 16059, Turkey

*Corresponding Author Email : eatasoy@uludag.edu.tr

Key words

Hydrochemical features,

Kazakhstan,

Yesil River Basin

\section{Publication Info}

Paper received : 16.10 .2016

Revised received : 20.06.2017

Accepted : 27.06.2017

\section{Abstract}

Aim: The aim of the present study was to examine the hydrochemical composition and geoecological features and to assess the level and nature of anthropogenic pollution in the Yesil river basin.

Methodology : Field studies are an integral part of observation and analysis of landscape components. Sample analysis of chemical composition of the Yesil river basin water was conducted in July-August 2016 to ascertain the current state of geo-environmental pollution of the basin water.

Results: Reduction of river water causes sharp deterioration in the sanitary condition of river. Great harm is caused by pollution by industrial, agricultural, municipal and domestic sewage. However, there is an increased content of $\mathrm{SO}_{4}{ }^{2 \cdot}, \mathrm{NO}_{3}$. and $\mathrm{NO}_{2}$, Fe and total salinity of water.

Interpretation: Systematic analysis of water quality in the Yesil indicates that the river copes with pollution mainly by the self-cleaning processes. Comparative analysis of qualitative and quantitative indicators of the Yesil river basin water surface indicates the presence of some of their relationship. The solution to the problem of stabilization and improvement of the ecological state of the Yesil river basin geosystems, under intensive anthropogenic impact, requires maximum consideration of the specific nature condition and the analysis of key factors and processes that affect its condition.

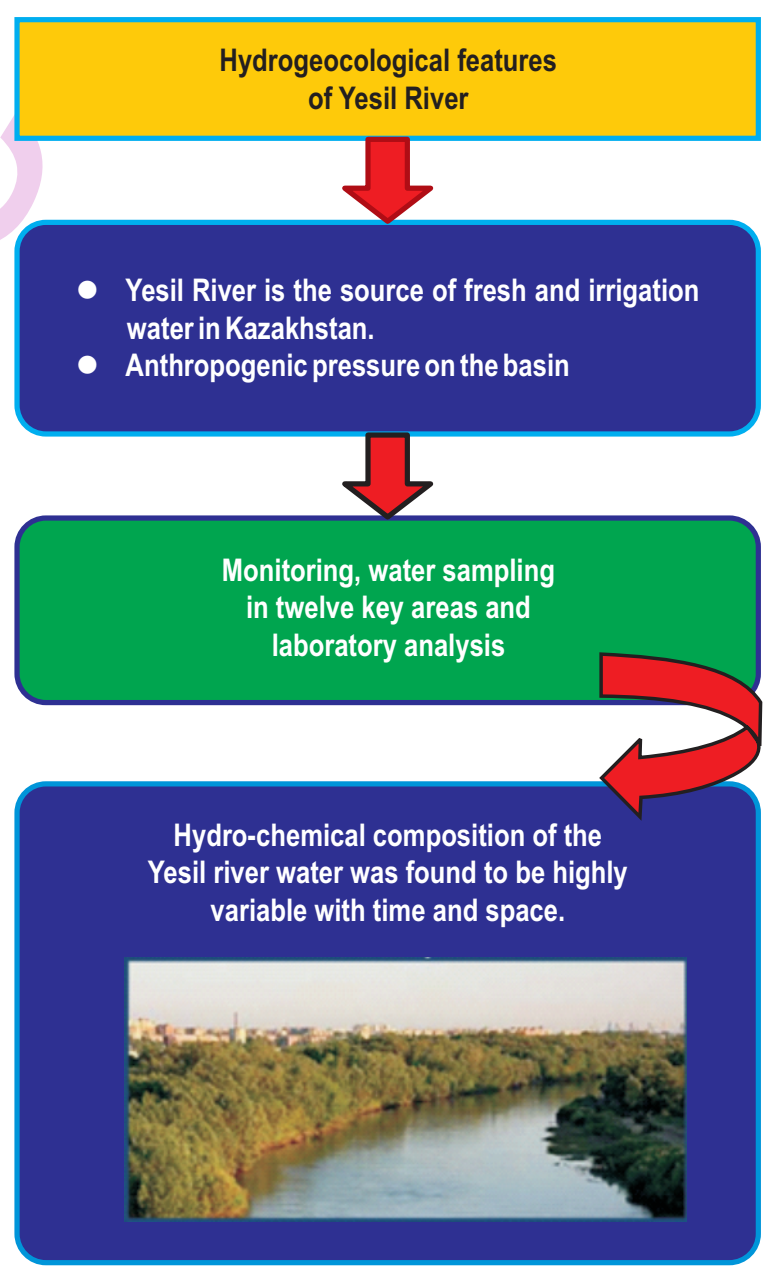




\section{Introduction}

The hydrological regime of many water bodies has significantly changed over the past decades. Water in rivers and lakes has become polluted with heavy metals, petroleum products, pesticides and other pollutants (Arora et al., 2016). Yesil river is an important water resource for the northern economic region of Kazakhstan, a source of fresh water and a source for irrigation. Yesil river basin geosystem is also subject to significant human impact, due to the agricultural and industrial activities. Growth and development of Kazakhstan's capital Astana have caused an increase of man-induced impact on the territory of Akmola region (Romanova and Tursunov, 2015). The development of the industrial and agricultural sectors, municipal sphere in the region is accompanied by water pollution by sewage and land runoff from the water-collecting area of reservoirs (Burlibayeva, 2013; Nor and Fitisova, 2014; Yermolaeva, 2015).

\section{Materials and Methods}

Study area: Yesil river in Kazakhstan and Russia is a left tributary of the Irtysh river. The average annual flow of the river is about 2,5 $\mathrm{km}^{3}$, water consumption is $76,0 \mathrm{~m}^{3} \mathrm{~s}^{-1}$. It originates from the springs in the Niaz mountains (northern outskirts of Kazakh upland). The total length of the river from its source to the mouth is $2451 \mathrm{~km}$, the catchment area is $155,000 \mathrm{~km}^{2}$, the average slope is 0,21\% (Dzhanaleyeva, 2010) .

Field survey and sampling: The main research task was to select key areas within the basin, which reflect the state of geosystems in key background areas and located in the zone of human impact. Twelve key areas were identified considering the types of environmental management and using the results of satellite imagery of high spatial resolution Landsat 5 TM obtained in 2012. Both traditional methods (key areas, landscape profiling, mapping, comparative geographical) and satellite imagery interpretation were used.

Field studies were conducted in July-August 2016 to ascertain the current state of geo-environmental pollution of the basin in the following areas: North Kazakhstan region: Dolmatovsky, Petropavlovsky, Yavlensky, Sergeyevsky and Novoishimsky. Akmola region: Vyacheslavsky, Promyshlennyi, Atbasarsky, Derzhavinsky, Esilsky, Aidabolsky and Karaganda region: Centralnyi. The key areas were selected in the territories of concentration of agricultural and industrial production.

\section{Results and Discussion}

Field studies aimed at estimating of hydro-chemical composition of water, and the study of ecological and physicalgeographical landscape condition of key areas were carried out in July-August 2016. In compiling of hydro-chemical analysis of the region scientific works of Kasimov (1988), Panin and Panina (2008),Sayet (1990), Gvozdetsky, (1978) were used. Further studies are planned for the period from 2017 to 2019. An expected dependence of chemical elements on the state of the hydrological regime of water and season was gradually established during the course of the study. One of the problems of the Yesil river is the reduction of the river flow in summer, when the water level is lowered so that the parts of the river bottom in shallow sections are exposed. Physical and geographical description of the landscape of the key areas where water samples were taken for hydro-chemical analysis is given in Table 1 (Medeu, 2010; Mendybayev et al., 2015; URL 1; Zhakupov etal., 2015).

Water sample analyzes were carried out in special accredited laboratories in Astana and Petropavlovsk. Taking in consideration the results of performed work the hydro-chemical composition of Yesil river water was analyzed (Table2).

On the basis of major ion content in Yesilbasin water salinity in 2016, the following conclusions can be drawn: the composition of the total salinity(dry residue) varies throughout the length of the river (Fig.1). The largest amount of dry residue according to the results of field studies was found in the area of Astana in the town Promyshlenyi - 1523,64 mg dm $\mathrm{m}^{-3}$, and the lowest amount in the key area of Yavlensky. The highest salinity was concentrated in the upper and middle reaches of the river Yesil, it reduced in the lower reaches and increased rapidly in Dolmatovsky key area.

The turbidity of river changed gradually. High level turbidity was registered in Derzhavinsk- 5.74. pH ranged from 7.5 to 8.14. The maximum amount of bicarbonate ions was registered in Atbasar key area and was $298 \mathrm{mg} \mathrm{dm}^{-3}$. The highest $\mathrm{Cl}^{-}$and $\mathrm{SO}_{4}{ }^{2-}$ content was registered in Promyshlenny-402.32 and 407.9 $\mathrm{mg} \mathrm{dm}^{-3}$ (Fig.2). The $\mathrm{NO}_{3}^{-}$and $\mathrm{NO}_{2}^{-}$content generally corresponded with the overall performance standards of MPC surface water bodies. The largest amount of suspended substances, $\mathrm{Ca}^{2+}$ and $\mathrm{Mg}^{2+}$ was registered in Derzhavin, sky and Atbasarsky key area.

In Akmola region, the salinity of Yesil river during spring filling reached $300-400 \mathrm{mg} \mathrm{l}^{-1}$, with hardness of 3-4 mg-Eq. (moderately hard). The ionic composition of water was characterized by predominance of three anions - $\mathrm{Cl}, \mathrm{SO}_{4}{ }^{2}$ and $\mathrm{Ca}^{2+}$ and $\mathrm{Na}^{+}$among cations. In summer salinity reached $600-$ $1000 \mathrm{mgl}^{-1}$ and increased in winter to $1,5 \mathrm{~g} \mathrm{~kg}^{-10}$.

The Yesil river water temperature ranged from $0.2^{\circ} \mathrm{C}$ to $16.8^{\circ} \mathrm{C}$; the average $\mathrm{pH}$ value was 7.31 ; the concentration of dissolved oxygen in the water was $10.78 \mathrm{mg} \mathrm{dm}^{-3} ; \mathrm{BOD}_{5}-1.96 \mathrm{mg}$ $\mathrm{dm}^{-3}$. Excess of MPC alignments were recorded in terms of heavy metal groups (Cu- 3,6 MPC), nutrients (Fe total, 2,1 MPC), major ions (SO-1,5 MPC, Na-1,3 MPC). The water quality of the Yesil river according to the newsletter "On the state of the environment «Kazhydromet» RSE estimated as of a moderate level of pollution as for the Republic of Kazakhstan"(Anonymous 1; Dostay, 2012), (Table 3). 
Table 1 : Description of key sections of Yesil river basin

\begin{tabular}{ll}
\hline Name & Location \\
\hline Yesilsky & $3 \mathrm{~km}$ from theYesil city to the northeast. The left bank of the river Kyzylsu. Hillocky area with shrub, oat grass and red feather \\
$51^{\circ} 59^{\prime} 24^{\prime \prime}$.lat. & grass vegetation on dark-chestnut alkali soils.
\end{tabular}

$66^{\circ} 24^{\prime} 20^{\prime \prime} E$.long.

Atbasarsky

$51^{\circ} 49^{\prime} 46^{\prime \prime} \mathrm{N}$. lat.

$68^{\circ} 23^{\prime} 29^{\prime \prime}$ E.long

Derzhavinsky

$51^{\circ} 07^{\prime} 13^{\prime \prime N}$.lat.

6619'49"E.long.

Aidabolsky

$52^{\circ} 41^{\prime} 46^{\prime \prime N}$.lat.

$68^{\circ} 59^{\prime} 45^{\prime \prime}$.long.

Novoishymsky

$53^{\circ} 12^{\prime} 55^{\prime \prime}$. lat.

$66^{\circ} 50^{\prime} 54^{\prime \prime}$ E.long.

Yavlensky

$54^{\circ} 21^{\prime} 40^{\prime \prime N}$.lat.

$77^{\circ} 72^{\prime} 68^{\prime \prime}$ E.long.

Sergeyevsky

$53^{\circ} 52^{\prime} 48^{\prime \prime N}$.lat.

$67^{\circ} 24^{\prime} 57^{\prime \prime}$. E.long

Dolmatovsky

$55^{\circ} 19^{\prime} 01^{\prime \prime} N$.lat.

$69^{\circ} 27^{\prime} 20^{\prime \prime} E$.long.

Petropavlovsky

54 $54^{\prime} 19^{\prime \prime}$. lat.

$69^{\circ} 74^{\prime} 79^{\prime \prime}$ E.long.

Vyacheslavsky

$51^{\circ} 00^{\prime} 21^{\prime \prime}$.lat.

$72^{\circ} 04^{\prime} 05^{\prime \prime}$ E.long.

Centralnyi

$50^{\circ} 38^{\prime} 28^{\prime \prime N}$.lat.

$72^{\circ} 50^{\prime} 58^{\prime \prime} E$.long.

Promyshlenyi

$51^{\circ} 38^{\prime} 45$ "N.lat.

$71^{\circ} 68^{\prime} 94^{\prime \prime}$.long.

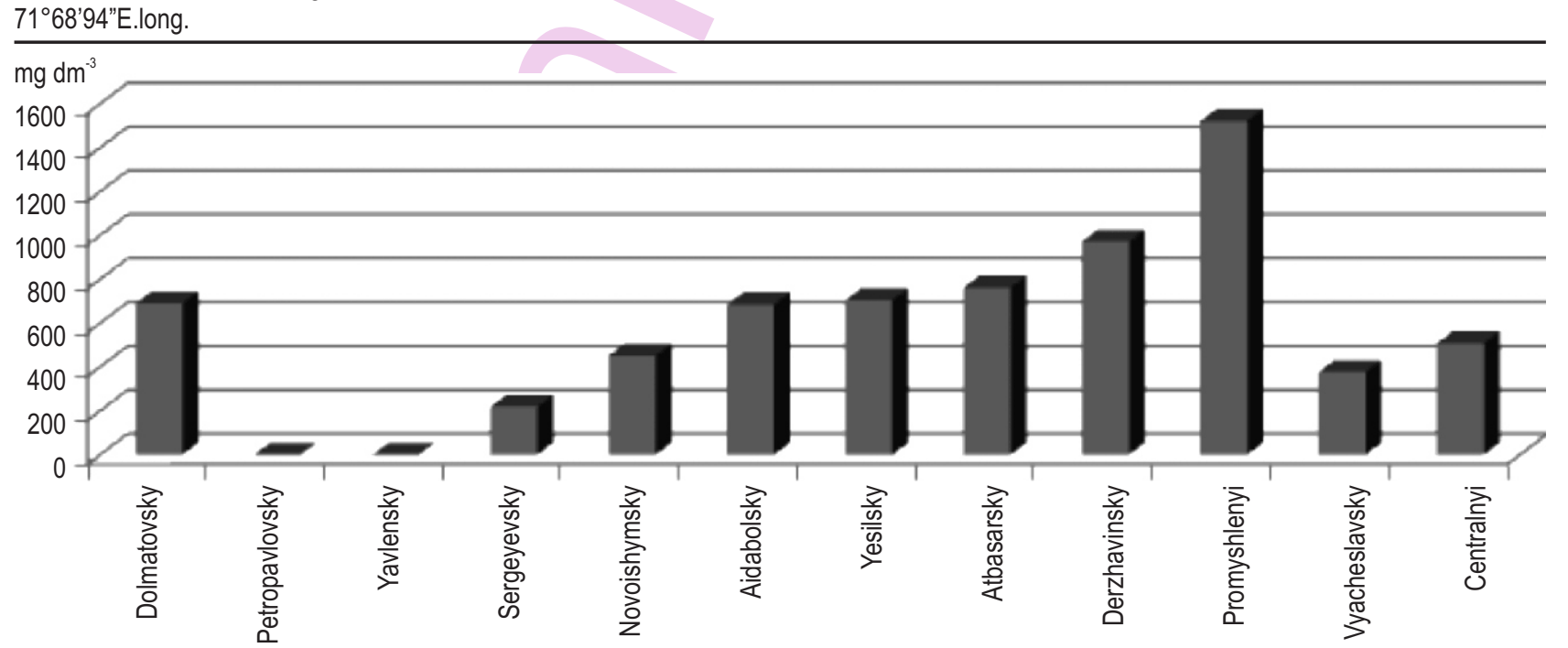

Fig. 1 : Total salinity $\left(\mathrm{mg} \mathrm{dm}^{-3}\right)$ of substances on the key areas of Yesil river in 2016
$2.5 \mathrm{~km}$ to the northwest of Atbasar city. The right bank of the Zhabai river. Denudation plain with mixed herbs and red feather grass vegetation on black soil southern carbonate and meadow-black soils.

$2 \mathrm{~km}$ to the northeast of Derzhavinsk city. The left bank of the Yesil river. Hillocky area with shrub,oat grass and red feather grass vegetation on dark-chestnut alkali soil.

$0.2 \mathrm{~km}$ to the southwest of village Aydabul. Denudation plain with mixed herbs and red feather grass vegetation, birch groves on ordinary normal black and underdeveloped soils.

$2.5 \mathrm{~km}$ from the village Novoishimsky. The left bank of the Yesilriver. Lake-alluvial plain with lake basins, mixed herbs and red feather grass vegetation with birch groves on ordinary black soils.

$2 \mathrm{~km}$ from the village Yavlenka to the northwest. The right bank of the Yesilriver. Lake-alluvial plain with mixed herbs and red feather grass vegetation on southern normal black soils, meadow-black and alkali soil.

$3 \mathrm{~km}$ from the village Sergeyevka to the southwest. The right bank of the Yesilriver. Lake-alluvial plain with mixed herbs and red feather grass vegetation on southern normal black soils, meadow-black and alkali soil.

$1,5 \mathrm{~km}$ from the village to the west. The right bank of the Yesil river. Lake-alluvial plain with birch and aspen forests in combination with mixed herbs vegetation, grain meadow plants on gray forest soils, ordinary black soils, meadow-black soils.

$1.6 \mathrm{~km}$ from Naberezhnaya Str. to the northeast. The right bank of the Yesilriver. Lake-alluvial plain with mixed herbs and red feather grass vegetationonordinaryand meadow-blacksoils.

$1.5 \mathrm{~km}$ to the northeast of village Vyacheslavka. Diluvial-proluvial plain with shrub,oat grass and red feather grass vegetation on carbonate black soils.

$8 \mathrm{~km}$ from the source of river. The left bank of the Yesil river. The left bank of the Ishim Reservoir to the southwest. Hillocky area with shrub, sheep grass, fescue grass and red feather grass vegetation on southern carbonate black soils and dark-chestnutalkali soil.

$7 \mathrm{~km}$ to the northwest of village Aleksandrovka. Diluvial-proluvial plain with shrub, oat grass and redfeather grass vegetation on carbonate black soils. 


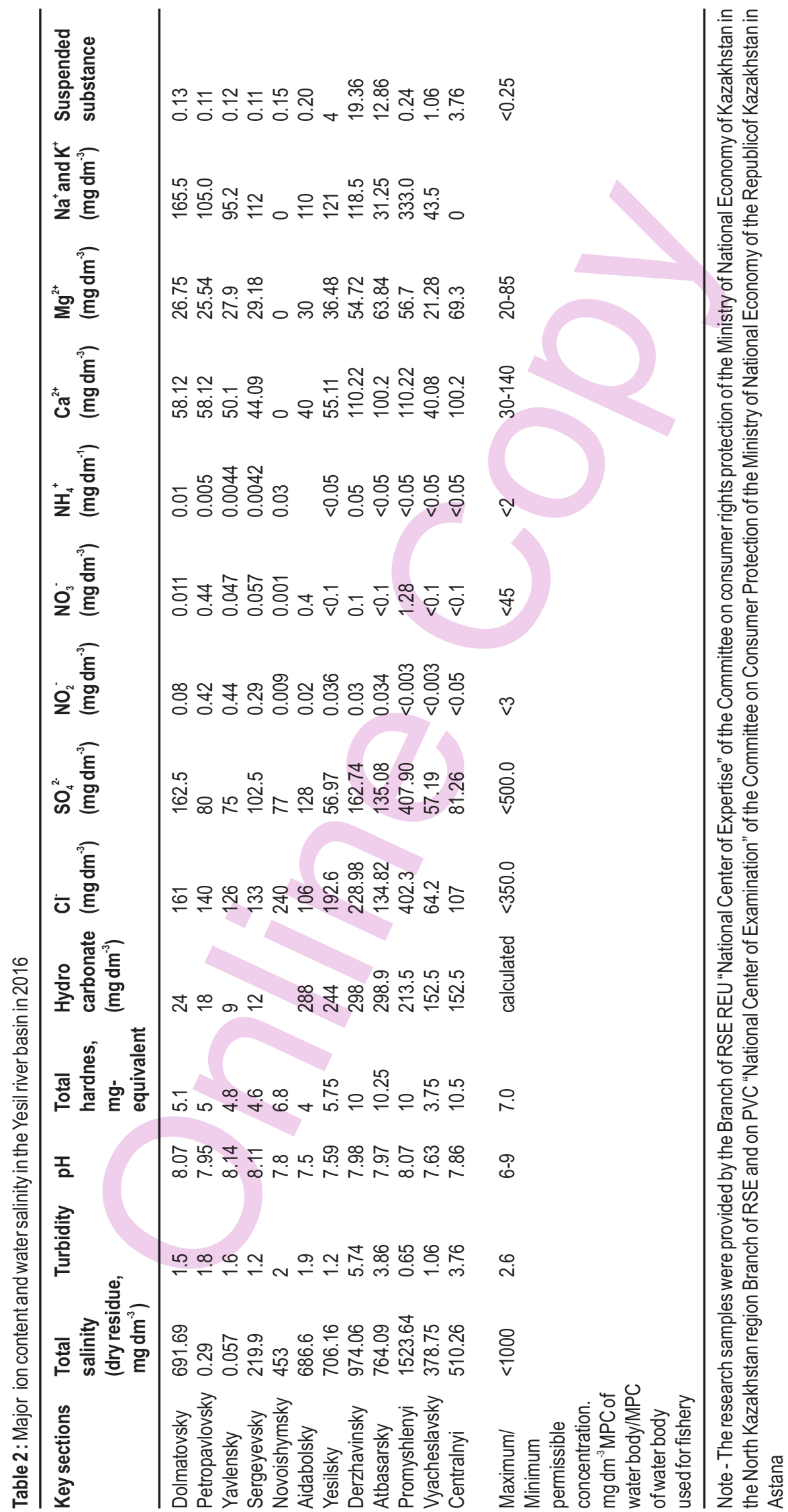




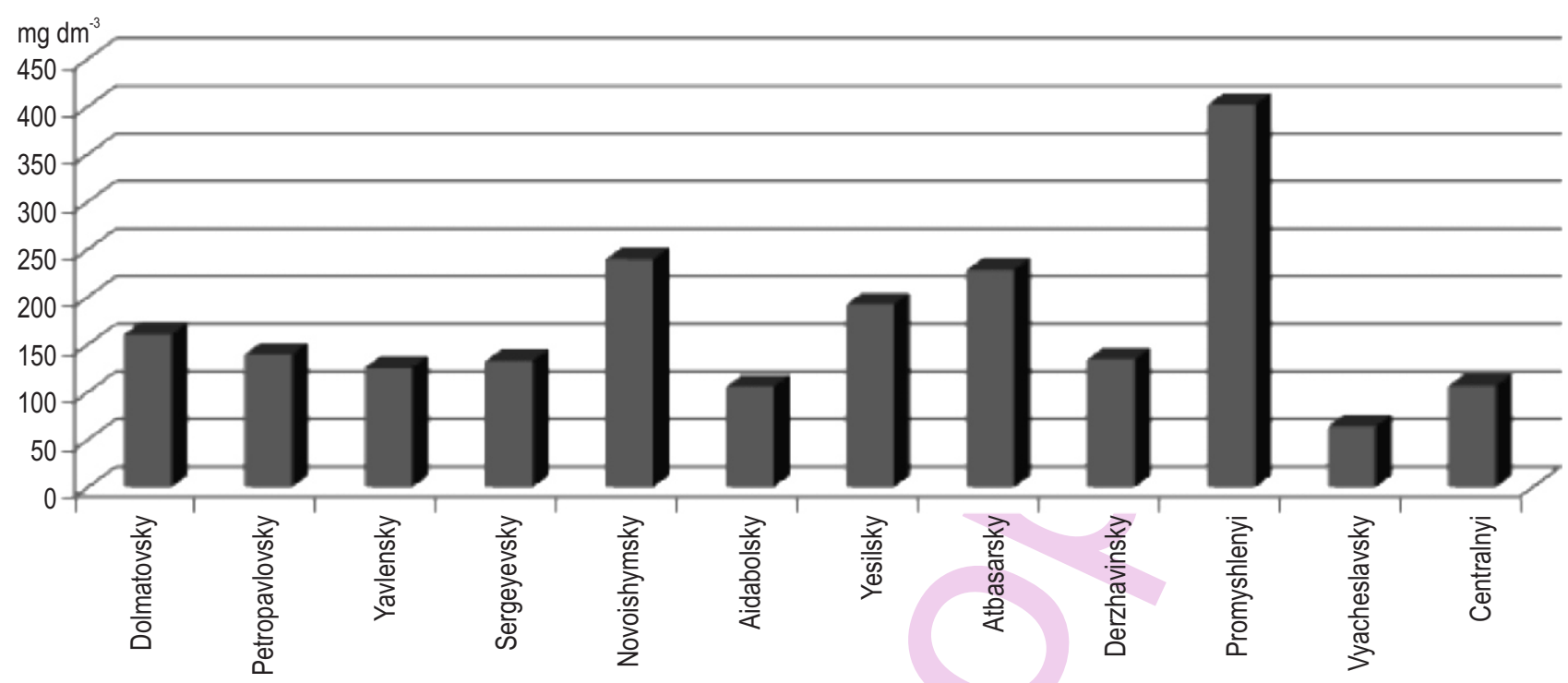

Fig. 2 : Chloride ion content $\left(\mathrm{mg} \mathrm{dm}^{-3}\right)$ in the water of the key sections of the Yesil river in 2016

Table 3 : Surface water quality state according to the hydro-chemical indicators (URL 1)

\begin{tabular}{|c|c|c|c|c|}
\hline \multirow[t]{2}{*}{ Source of water } & \multicolumn{2}{|c|}{$\begin{array}{l}\text { A comprehensive water pollution index (CWPI) } \\
\text { and a class of water quality }\end{array}$} & \multicolumn{2}{|c|}{ Pollutant content in the 1 st half of 2016} \\
\hline & 1-sthalf of 2015 & Water quality indicators & Water quality indicators & The average concentration. $\mathrm{mg} \mathrm{dm}^{-3}$ \\
\hline \multirow[t]{7}{*}{ Yesil (NKR) } & 10.0 (permissibly clear) & 10.78 (permissibly clear) & Dissolved oxygen & 10.78 \\
\hline & 1.46 (permissibly clear) & 1.96 (permissibly clear) & $\mathrm{BOD}_{5}$ & 1.96 \\
\hline & $\begin{array}{l}1.92 \text { (moderate level of } \\
\text { pollution) }\end{array}$ & $\begin{array}{l}2.37 \text { (moderate level of } \\
\text { pollution) }\end{array}$ & Majorions & \\
\hline & & & $\begin{array}{l}\mathrm{SO}_{4} \\
\mathrm{Na}\end{array}$ & $\begin{array}{l}145 \\
157.3\end{array}$ \\
\hline & & & Biogenic substances & \\
\hline & & & $\begin{array}{l}\text { Fe } \\
\text { Heavy metals }\end{array}$ & 0.21 \\
\hline & & & $\mathrm{Cu}$ & 0.0036 \\
\hline \multirow[t]{7}{*}{ Yesil(Akmolinskaya) } & 7.64 (permissibly clear) & 9.80 (permissibly clear) & Dissolved oxygen & 9.80 \\
\hline & 1.74 (permissibly clear) & 1.57 (permissibly clear) & $\mathrm{BOD}_{5}$ & 1.57 \\
\hline & $\begin{array}{l}3.05 \text { (moderate level of } \\
\text { pollution) }\end{array}$ & $\begin{array}{l}2.46 \text { (moderate level of } \\
\text { pollution) }\end{array}$ & Major ions & \\
\hline & & & $\begin{array}{l}\mathrm{SO}_{4} \\
\text { Heavy metals }\end{array}$ & 170 \\
\hline & & & $\mathrm{Cu}$ & 0.0017 \\
\hline & & & Ìn & 0.044 \\
\hline & & & $\mathrm{Zn}$ & 0.036 \\
\hline
\end{tabular}

The predominance of snow feeding of the river Yesil determines a sharp decrease of water in spring during a brief and intense spring flood. According to long-term data, water salinity at this time water $130-400 \mathrm{mg}$ I with predominance in the ionic composition of bicarbonate ions and $\mathrm{Ca}$ (Dostay, 2012).

In the middle reaches of the river, water was characterized by the predominance of $\mathrm{Cl}^{-}$in all seasons. Often, such composition is observed in the freshet. Change in the chemical composition of middle reaches of the river is determined by strong growth in this section of the catchment area (different in chemical composition) from $7.4 \mathrm{~km}^{2}$ in Astana to $118 \mathrm{~km}^{2}$ in Petropavlovsk, and an increase in the water content of the river from 0.34 to $2.11 \mathrm{~km}^{2}$ due to a confluence of many tributaries. At low water, in connection with the transition to groundwater feeding, its salinity increased sharply and reached 600-700 $\mathrm{mg} \mathrm{I}^{-1}$ and in winter to $2900 \mathrm{mg} \mathrm{l}^{-1}$ (Dostay, 2012; Dostay, 2013), respectively. 
Table 4 : Changes in salinity $\left(\mathrm{mg} \mathrm{dm}^{-3}\right)$ and ionic composition of Yesil river along the length (annual average)

\begin{tabular}{|c|c|c|c|c|c|c|c|c|c|}
\hline \multirow[t]{2}{*}{ Point } & \multicolumn{6}{|c|}{ Ionic composition ( $\mathrm{mg} \mathrm{dm}^{-3}$ ) } & \multicolumn{3}{|c|}{ Salinity $\left(\mathrm{mg} \mathrm{dm}^{-3}\right)$} \\
\hline & $\mathrm{Ca}$ & Mg & $\mathrm{Na}+\mathrm{K}$ & $\mathrm{HCO}$ & so & $\mathrm{Cl}$ & $\min$ & $\max$ & annual average \\
\hline Astana & 80,0 & 30,3 & 129,0 & 232 & 133 & 179 & 130 & 1750 & 756 \\
\hline Petropavlovsk & 68,8 & 31,0 & 142,0 & 233 & 143 & 174 & 158 & 2900 & 792 \\
\hline
\end{tabular}

Water salinity at the top, despite of significant differences in water content of the river and the composition of the water of inflows in these areas, is characterized by close in number and the average annual sum of the main ions for a number of years in the head of the river was $757 \mathrm{mgl}^{-1}$, and in the middle it reached to $792 \mathrm{mgl}^{-1}$ (Table 4) (Dostay, 2013).

Thus, the chemical composition of Yesil river water was highly variable with time and space. In general, the Yesil river tributaries have a similar chemical composition. They are characterized by large amplitude of variation of salinity within a year from $150 \mathrm{mg} \mathrm{l}^{-1}$ to $3-4 \mathrm{~g} \mathrm{l}^{-1}$, and by changing the ionic composition from hydrocarbonate-sodium, calcium to chloridesodium. The waters of numerous tributaries, along with other climatic factors have a significant influence on the formation of hydro-chemical regime of the Yesil river. Within-year variability in the concentration of ions in the water is connected with the water regime of the river. The lower limits of salinity and concentration of major ions is observed in the upper reaches of the river in April and in the middle reaches in May. The relative content of individual ions during the course of the year was not constant; therefore there was a change in the functional relation between salinity and individual ions. With 200-500 mg ${ }^{-1}$ salinity, predominance of $\mathrm{HCO}_{3}{ }^{-}$and $\mathrm{Ca}^{2+}$ ions was observed and with 500 $\mathrm{mg} \mathrm{I}^{-1}$ salinity and more, the domination of $\mathrm{Cl}^{-}$and $\mathrm{Na}^{+}$and $\mathrm{K}^{+}$was recorded.

\section{References}

Anonymous: Newsletter of the Republic of Kazakhstan state of the environment in the 1st half of 2016 /Ministry of Environmental Protection of the Republic of Kazakhstan, Astana (2016).

Arora, T., A. Mishra, G. Matta, A.K. Chopra, A. Kumar., D.R. Khanna and V. Kumar: Pollution lad assessment and potential environmental risks of composite industrial effluents discharged from SIIDCUL Integrated Insdustrial Estate, Haridwar (Uttarakhand), India. J. Env. Biol., 38, 205-216 (2017).
Burlibayeva, D.M., A.T. Tleukulov, C. Opp and I. Kirvel: Changes in hydro-chemical regime characteristics of transboundary Ishim river. Słupskie Prace Geograficzne, 10, 5-20 (2013).

Dostay, Z.D.: Water resources of Kazakhstan: Assessment, prediction and control. In: Natural Water Bodies of Kazakhstan: Resources, Regime, Quality and Forecast, Almaty (2012).

Dostay, Z.D.: Water resources of Kazakhstan: Assessment, prediction and control. In: Resources of Rivers Flow of Kazakhstan (2013).

Dzhanaleyeva, G.M.: Physical geography of the Republic of Kazakhstan. - Astana: L.N. Gumilyov Eurasian National University, Arcas (2010).

Gvozdetsky, N.A.: Landscape map of the Kazakh SSR, Almaty (1978).

Kasimov, N.S.: Geochemistry of the steppe and desert landscapes. Moscow State University (1988).

Mendybayev, E.H., G, Atayeva, Z.Z. Berdenov and E. Atasoy: Geochemical researches of region soil with technogenic influence in terms of Borlinsky region, West Kazakhstan. Oxid Commun., 38, 1933-1941 (2015).

Medeu, A.R.: The National Atlas of the Republic of Kazakhstan, Almaty (2010).

Nor, P.Y. and M.S. Fitisova: The Assessment of the Ecological State of the Ishim River Basin. Yong Scient., 5, 183-185 (2015).

Panin, M.S. and M. I. Panina: Hydrochemistry of underground waters of Semipalatinsk Priirtyshye of the Republic of Kazakhstan. The 5th International scientific-practicalconference 'Heavy metals and radionuclides in the environment. Semey (Kazakhstan); Proceedings, pp. 413-416 (2008).

Romanova, S.M. and E.A. Tursunov: Surface waters quality in Kazakhstan and issues of International of Water Allocation. Almaty (2015).

Sayet, Y.Y.: Geochemistry of the Environment, Nedra (1990).

Yermolaeva, N.I.: Zooplankton and water quality of the Ishim river in northern Kazakhstan. Arid. Ecosystems, 5, 176-187 (2015).

Zhakupov, A.A., K. Saparov and E. Atasoy: Fundamentals of recreationgeographic assessment for tourism development. Oxid Commun., 38, 871 (2015).

URL 1: Kazhydromet the Republic of Kazakhstan, in the section «Environmental Monitoring» http://www/kazhydromet.kz. 